\title{
Os cinco macacos e o pensamento crítico
}

\section{Ronaldo Baltar}

February 27, 2017

\section{Os cinco macacos e o pensamento crítico}

De tempos em tempos, alguém faz circular a famosa estória motivacional dos cinco macacos. E sempre resulta em muitos comentários positivos. Neste início de 2017, não foi diferente. Várias postagens, em diferentes redes, lembraram a estória que estimula as pessoas a pensarem diferente do senso comum. Uma espécie de convite ao pensamento crítico.

Resumidamente, para quem nunca recebeu um post ou e-mail com essa narrativa, a estória se inicia com o relato de um experimento científico. Um grupo de pesquisadores pendurou um cacho de bananas no teto de uma jaula com uma escada embaixo. Na jaula havia cinco macacos. Quando um dos macacos, após algum tempo observando a situação, subiu na escada para pegar as bananas, todos receberam um jato d'água fria. Passado algum tempo, outro macaco tenta subir na escada e todos novamente são alvo do jato de d'água. Logo, quando um dos macacos demonstra a intenção em subir a escada, os demais o impedem. O experimento segue, um dos macacos é trocado e não há mais jato d'água. Quando o novato tenta subir na escada para pegar as bananas, os quatro que presenciaram a situação anterior o impedem. O novato tenta e novamente é impedido. Os macacos são trocados um a um, e a cena se repete.

Ao final do experimento, mesmo sem ter presenciado a situação desagradável inicial, os macacos não tentam mais subir na escada para pegar a banana.

Por que não? Porque, para os macacos, esse era o jeito de se fazerem as coisas.

Com essa ilustração, o texto quer instigar as pessoas a serem críticas, criativas e inovadoras. A mensagem é: porque continuar a fazer as coisas do jeito que todos fazem?

Desde que lançada, a estória tornou-se viral. Apareceu inicialmente em 2011, no blog do escritor Michael Michalko, autor de vários textos motivacionais sobre criatividade nos negócios, entre os quais: "Creative Thinkering: putting your imagination to work".

Convida o leitor a ter uma visão crítica: será que você não é como um macaco do experimento, aquele que reproduz o mesmo jeito de fazer as coisas sem saber o motivo?

Você já se sentiu repreendido pelo grupo quando tentou fazer algo 
diferente? Já te disseram não faça isso; você perguntou: - por que não? E te disseram: - porque aqui é assim que as coias são?

Provavelmente a grande maioria dos leitores dirá sim a estas perguntas embutidas no texto. Talvez isso explique o sucesso que essa estória faz.

Desde que recebi pela primeira essa mensagem (e já foram inúmeras!), chamou-me a atenção a ampla aceitação positiva dessa narrativa. Parece demonstrar que muitas pessoas buscam ter um pensamento crítico em relação ao senso comum. Não querem ser conformadas, não querem apenas seguir o rebanho, seja no trabalho ou na vida. Querem entender o meio do qual fazem parte e querem fazer diferença. Querem saber como a história nos fez o que somos. Do mesmo modo que querem saber interagir para mudar, construir um caminho futuro, do jeito que queremos ou podemos ser. Isso é muito bom.

Mas, por outro lado, a simplicidade com que a estória é contada ( e repassada ) parece indicar também o contrário, mais do mesmo.

Uma postura criativa e inovadora, requer de fato um pensamento crítico. E pensamento crítico significa rever conceitos préestabelecidos.

Mas o pensamento crítico se faz a partir do acúmulo de conhecimento, não da negação da experiência adquirida como indiretamente sugere a estória dos cinco macacos. Mais importante do que isso, as instituições têm um papel fundamental na criação do ambiente inovador.

Apostar que um indivíduo possa ir adiante, contra o senso comum de uma empresa ou instituição não preparada para mudanças, é ingênuo.

A estória dos cinco macacos enfatiza que quem tolhe as iniciativas são os colegas. Mas na verdade, são as instituições, não os indivíduos, que criam um ambiente favorável ou inibidor da crítica e da diversidade. São os indivíduos que reagem, interagem e criam alternativas. Mas são as instituições que controlam o jato de água fria e o experimento como um todo.

O ponto de partida do pensamento crítico deve ser uma problematização da realidade. Em seguida tem que se capacitar para buscar entender a situação, por meio de informações e conhecimento sobre a realidade. O próximo passo seria o de separar, organizar, classificar, hierarquizar os fatos conhecidos (a isso se chama analisar, e, para que haja uma boa análise, há de se ter método). Por fim, faz-se a proposição de alternativas mais adequadas para o problema inicial. Daí surge a inovação. A criatividade que retira do nada soluções novas é magia. A criatividade que formula solução a partir da análise da experiência acumulada, está sim gera conhecimento e tem impacto institucional. 
A narrativa dos cinco macacos parte de um dogma, pois fala do relato de um experimento científico. Com isso, induz o leitor a crer, por princípio, que se trata de uma experiência inquestionável. O curioso é que o adjetivo científico deveria significar exatamente o oposto. Um conhecimento científico é aquele obtido por um método demonstrável e passível de ser questionado. Mas é tratado erroneamente como uma afirmação inquestionável.

A "experiência científica" que deu origem à estória dos cinco macacos não existiu. É uma narrativa ficcional criada por Michalko. Supõem-se que tenha sido inspirada pelo experimento (este sim real) do Prof. Gordon Stephenson, do Departamento de Zoologia da Universidade de Wisconsin, publicado em 1966, no artigo: Cultural Acquisition of a Specific Learned Response among Rhesus Monkeys (link).

No artigo do Prof. Stephenson, pares de macacos Rhesussão usados para testar se há transmissão de conhecimento entre essa espécie. Não são cinco macacos, não há banana pendurada no teto, não há jato d'água fria. A pergunta da pesquisa do Professor de Zoologia de Wisconsin era bem mais objetiva: há transmissão de comportamento adquirido entre os animais?

No experimento real, os pares eram compostos por um animal condicionado a evitar um alimento (com jatos de ar, não água) e outro não condicionado. Stephenson queria saber se o animal condicionado (ele chamava de "demonstrador") transmitiria o seu "conhecimento" para aquele não condicionado (que ele denominava de "ingênuo").

Quem ler o artigo verá que a conclusão do estudo é bem diferente da conclusão do texto sobre os cinco macacos. Na pesquisa real, em alguns pares, o macaco ingênuo copiou o comportamento do macaco condicionado (como reproduzido na estória dos cinco macacos). Em outros pares não. Houve pares em que se deu o contrário, o animal "ingênuo" acabou influenciando o macaco demonstrador, que passou por cima do seu condicionamento inicial e comeu o alimento (o oposto da estória dos cinco macacos). A narrativa dos cinco macacos não tem relação alguma com a realidade.

Na ficção dos cinco macacos, o novato é impedido pelos outros de se aproximar da escada, pois os veteranos sabem, por experiência o que receiam: o jato d'água fria. $\mathrm{O}$ macaco novato ignora o alerta e é repreendido pelos demais. O macaco novato apanha e se conforma. $\mathrm{O}$ leitor se identifica com o macaco novato e lamenta todas as vezes que teve uma iniciativa e foi tolhido. Jura que não vai mais ser como o macaco no experimento da vida ou da empresa em que trabalha.

Vamos ver esse experimento imaginativo por outro ângulo. Note que apenas os observadores (os pesquisadores na estória fictícia) sabem que não há mais jato d'água. Os macacos não sabem se haverá 
ou não jato d'água fria e estão confinados em uma jaula, não têm por onde sair. Logo, para os cinco macacos, a água fria continua a ser uma possibilidade concreta. O risco é real. Quem impõe o risco e incentiva o comportamento não criativo são os empreendedores do experimento, no caso, os cientistas imaginários.

A narrativa humaniza os possíveis comportamentos dos cinco macacos. Seguindo essa linha, vamos supor que o novato, ao entrar na jaula, não fosse informado pelos demais sobre o perigo de se aproximar das bananas. Os veteranos sabiam, mas não disseram nada. Seria uma atitude racional para o grupo? Certamente, não. Os macacos fictícios, ao socializarem sua experiência, minimizaram o risco existente, representado pelos gestores do experimento que continuavam com a mangueira a postos. Ou seja, para eles, compartilhar a informação era uma forma de minimizar o risco a que todos estavam submetidos.

Ao final do experimento, nenhum dos cinco macacos tinha visto o jato d'água. Mas porque teriam motivos para desconfiar da informação repassada a eles? Os primeiros macacos de fato receberam a carga desagradável de água fria. Essa era a única informação concreta disponível.

Você, se estivesse lá, arriscaria subir a escada, descartando a experiência dos seus companheiros?

Se um macaco novato tentasse subir a escada, o que você faria? Incentivaria o novato ou tentaria dissuadi-lo, pois as consequências do ato dele recaria sobre todos?

A estória é muito usada para motivar trabalhadores em empresas. Tem o foco no indivíduo. Mas o problema maior são as instituições, a jaula, o jato d'água controlado pelos os observadores de fora.

Os macacos da estória talvez não fossem conformados afinal. Simplesmente, não confiavam que os cientistas (as instituições, os gestores) não iriam jogar-lhes água fria. Você confiaria?

A estória dos cinco macacos é apenas uma versão pseudo-científica do velho adágio "gato escaldado tem medo de água fria".

Pensamento crítico não significa apenas olhar para o lado oposto, fazer o que outros não fazem. Conhecimento é um produto coletivo. Desprezar a experiência acumulada é um erro. Entre o conformismo e a ingenuidade voluntarista, deve-se optar pelo conhecimento profundo da situação. Nem todos que identificam um problema corretamente, tem uma solução correta para o mesmo problema. Por isso, inovar requer um pensamento crítico coletivo, cujo ponto de partida está na experiência concreta. Para tanto, é necessário que as instituições criem condições para aprendizagem e compartilhamento da experiência comum adquirida. A partir daí, as pessoas devem ser incentivadas a identificar onde estão limites do conhecimento atual. 
Com base nessas informações é que se pode analisar a realidade de maneira criativa. A instituição deve incentivar as pessoas a indagar, formular perguntas e propor alternativas. Individualmente, as pessoas devem ser incentivadas a se capacitarem antes de julgarem as ações dos outros e as suas próprias. O comportamento individual intolerante é nocivo não só à criatividade, mas à própria ideia de vida grupo, ou seja, à própria instituição. A intolerância não deve ser institucionalmente tolerada de forma alguma.

A inovação não é produto apenas da ação individual, é um resultado de grupo. Por isso, é papel das instituições criar as condições coletivas para a inovação e a criatividade, começando por dar confiança e garantir que o pensamento novo, a diversidade de ideias e de opiniões não serão tratados com água fria.

Publicado originalmente em https://www. linkedin. com/pulse/ os - cinco - macacos - e- o- pensamento - cr\%C $3 \%$ ADtico - ronaldo - baltar? published $=\mathrm{t}$

LinkedIn Pulse 